Al-Mashlahah: Jurnal Hukum dan Pranata Sosial Islam, VOL : 07, NO : 1, Agustus 2019

DOI : $10.30868 /$ am.v7i1.547

ISSN : 2339-2800 (Media Cetak)

ISSN : 2581-2556 (Media Online)

\title{
KONTRIBUSI MUI DALAM PENGEMBANGAN DAN PENERAPAN HUKUM ISLAM DI INDONESIA
}

\author{
Mumung Mulyati ${ }^{1}$ \\ ${ }^{1}$ Prodi Perbankan Syariah FAI UNINUS Bandung \\ email: mumungmulyati2017@gmail.com
}

\begin{abstract}
Islam is a religion that regulates the order of life and human life in relation to Allah S.W.T., fellow human beings, and the universe. The Indonesian Ulama Council (MUI) as an institution that issues Fatwa/Law has made a major contribution in establishing legal norms (religion), as well as being a guide in directing the lives of Muslims who carry out Islamic law in various activities of daily life. This research is based on a qualitative method using a library study approach with the main theory being the shahadah theory and the application theory of taqnin al-ahkam. Muslims accept Islam as their religion based on the commands of Allah and His Messenger, surely they believe the authority of Islamic law over him. So that he is ready to practice Islamic teachings, including the laws they contain. The researcher concluded that the MUI had contributed to the development and application of Islamic law in Indonesia was divided into two parts; first, the contribution or contribution to legal certainty for Muslims themselves individually or groups of Muslims and second, to taqnin for the fatwas that have been made. And some MUI fatwa products have been transformed into laws, Government Regulations (PP); Presidential Instruction and so on.
\end{abstract}

Keyword: fatwa, taqnin al-ahkam, legal development.

\begin{abstract}
ABSTRAK
Islam merupakan agama yang mengatur tata hidup dan dan kehidupan manusia dalam hubungannya dengan Allah S.W.T., sesama manusia, dan alam semesta. Majelis Ulama Indonesia (MUI) sebagai lembaga yang mengeluarkan fatwa/hukum telah memberikan kontribusi besar dalam pembentukan norma-norma hukum (agama), serta menjadi pemandu dalam mengarahkan kehidupan muslim yang melaksanakan hukum Islam dalam berbagai kegiatan kehidupan sehari-hari. Penelitian ini berdasarkan metode kualitatif menggunakan pendekatan studi kepustaakaan dengan teori utama adalah teori syahadah dan teori aplikasi taqnin al-ahkam. Orang Islam menerima Islam sebagai agamanya berdasarkan perintah Allah dan Rasul-Nya, niscaya mereka meyakini otoritas hukum Islam terhadap dirinya. Sehingga dia telah siap menjalankan ajaran Islam, termasuk hukum-hukum yang dikandungnya. Peneliti menyimpulkan MUI telah berkontribusi dalam pengembangan dan penerapan hukum Islam di Indonesia adalah terbagi kepada dua bagian; pertama, kontribusi atau sumbangsih pada kepastian hukum bagi umat Islam itu sendiri secara individu atau kelompok umat Islam dan kedua, pada taqnīn atas fatwa-fatwa yang telah dibuat. Dan sebagian produk fatwa MUI sudah bertransformasi kepada undang-undang, Peraturan Pemerintah (PP); Inpres, dan lain sebagainya.
\end{abstract}

Keyword: fatwa, taqnin al-ahkam, pengembangan hukum. 


\section{A. PENDAHULUAN}

Keberadaan Majelis Ulama Indonesia (MUI) dipandang sangat penting keberadaannya, yakni pada posisi memberikan fatwa (ift $\left.\bar{a}^{\prime}\right)$. Proses produksi fatwa bukan pekerjaan mudah yang dapat dilakukan oleh setiap orang melainkan pekerjaan sulit dan mengandung resiko teologis. Hal ini mengingat tujuan pekerjaan tersebut adalah menjelaskan hukum Allah kepada masyarakat yang akan mempedomani dan mengamalkannya. Oleh karena itu, tidaklah mengherankan jika seluruh kitab ushūl fiqh yang membicarakan ifta (produk fatwa) menetapkan sejumlah $a d \bar{a} b$ (kode etik) dan persyaratan sangat ketat dan berat yang harus dipegang teguh oleh setiap orang yang akan mengeluarkan/menetapkan fatwa.

Dari sudut hukum nasional, fatwa itu memang tidak mengikat akan tetapi yang mengikat adalah norma yang dijadikan norma hukum yang kemudian ditetapkan keberlakuanya oleh negara (al-taqnīn). Di dalam masyarakat norma atau kaidah itu banyak dijadikan pedoman bertingkah laku. Di antara norma terserbut adalah norma keagamaan, norma kesusilaan, norma kesopanan, dan norma hukum.

Norma yang mengikat sudah dipaksakan keberlakuanya melalui aparat negara, misalnya norma hukum yang telah dikeluarkan oleh lembaga berwenang dijadikan undang-undang, bukan karena melanggar hukum agama. Dengan demikian ini merupakan transformasi hukum Islam ke dalam hukum nasioal. Norma agama dapat dijadikan hukum jika disahkan untuk dijadikan undang-undang (UU) pada level nasional, Peraturan Pemerintah (PP) atau Peraturan Daerah (PERDA) pada tingkat provinsi atau kabupaten/kota.

Kedudukan fatwa bagi umat Islam menempati posisi yang sangat penting yang akan digunakan sebagai rujukan, karena fatwa dibuat dan dikeluarkan oleh orang-orang yang memiliki otoritas dalam bidang keagamaan. Fatwa MUI merupakan salah satu tuntunan umat yang membutuhkan kepastian dalam menjawab permasalahan yang ditanyakan. Mahfud MD., mengatakan bahwa kedudukan MUI sebagai pembelajaran hukum, termasuk hukum Islam. Oleh sebab itu, masalah kedudukan fatwa yang sifatnya tidak 
mengikat itu bisa saja dijelaskan baik dari hukum nasional maupun hukum Islam itu sendiri. Keberadaan MUI sendiri adalah sebagai pembimbing umat yang sekaligus menjadi jembatan antara umat dan Pemerintah. ${ }^{1}$

Prinsip dan persyaratan tersebut dalam melakukan ijtihad, sebagaimana dilakukan oleh MUI di antaranya ialah, bahwa seorang mujtahid (orang berijtihād) 2 harus mengetahui, mamahami hukum Islam secara mendalam beserta dalil-dalilnya baik yang berkenaan dalil, ayat-ayat tentang hukum maupun hadits-hadits tentang hukum. Tidak dibenarkan berfatwa hanya didasarkan pada keinginan dan kepentingan tertentu atau dugaandugaan semata tanpa didasarkan pada dalil. Setiap menyatakan suatu hukum haruslah dapat menunjukkan dalilnya; baik Alquran, Hadits maupun dalil-dalil hukum yang lainnya. Apabila menyatakan hukum tanpa didasarkan pada dalil-dalil tersebut disebut dengan tahākkum (mengada-ada dalam membuat hukum); maka perbuatan

\footnotetext{
1 https://news.detik.com/berita/3397842/ mahfud-md-fatwa-mui.

2 Mujtahīd dalam fiqh dikategorikan kepada tiga bagian; mujtahīd mutlaq, mujtahīd fardi, dan mujtahīd fi al-madzhab.
}

tahākkum harus dihindari karena perbuatan itu dosanya sangat berat.

Islam pada hakekatnya adalah agama pembangunan yang mengatur tata hidup dan kehidupan manusia dalam hubungannya dengan Allah, sesama manusia, dan alam semesta menuju keebahagian dan kesejahteraan hidup lahir bathin dan dunia akhirat, kesemuanya itu dapat dicapai dengan berpedoman kepada sumber hukum, baik Alquran maupun Hadits.

Majelis Ulama Indonesia (MUI) sebagai lembaga yang berkompeten untuk mengeluarkan fatwa/hukum, sudah tentu Ushül Fiqh akan dijadikan sebagai alat atau sarana dalam menggali, mengeluarkan atau menetapkan hukum untuk segala permasalahan yang tidak ada ketetapannya baik dalam Alquran, Hadits atau dalam kitab-kitab fiqh. Ushūl Fiqh sebagai sarana untuk menetapkan hukum sebagaimana dikemukakan oleh Abdul Wahab Khalaf yang memberikan pengertian sebagai berikut:

"Ilmu tentang kaidah-kaidah dan pembahasannya yang merupakan cara untuk menemukan hukum syara' yang amaliah dari dalil-dalilnya yang 
terperinci atau kumpulan kaidahkaidah yang merupakan cara untuk menemukan (mengambil) hukum syara' yang amaliah dari dalili-dalilnya yang terperinci", 3

Kaidah-kaidah yang terdapat dalam Ushul Fiqh merupakan prinsip yang bersifat umum yang notabene harus diperhatikan pemgecualiannya apabila terjadi ada qarînah-qarînah (tandatanda, alasan-alasan) yang menyimpangkan, misalnya; kata perintah (amr) asalnya menunjukkan wajib, beralih menjadi tidak wajib dan bertransformasi kepada status hukumhukum yang lainnya.

Fatwa MUI sebagaimana halnya fikih hasil ijtihad dari mujtahid, telah memberikan kontribusi besar dalam pembentukan norma-norma hukum (agama), serta menjadi pemandu dalam mengarahkan kehidupan muslim yang melaksanakan hukum Islam dalam berbagai kegiatan kehidupan seharihari; walaupun tidak mempunyai daya paksa secara hukum, namun kenyataanya ditaati dan berlaku efektif. Demikian pula fikih sebagai jabaran normatif dari syari'ah dan fatwa sebagai

3 H.A. Djazuli. (2006). Islam Fiqh: Penggalian, Perkembangan dan Penerapan Hukum Islam. Jakarta: Rosdakara. hlm. 7. pendapat hukum atau ketetapan dari mufti (pemberi fatwa) mengenai masalah tertentu dalam rangka penerapan syari'ah tidak memiliki daya paksa secara hukum (law inforcement), melainkan terletak pada sangsi moral dan emosi keagamaan atau adanya perasaan bersalah (quality feeling). ${ }^{4}$

Hukum Islam adalah syariat Allah S.W.T. yang bersifat menyeluruh berupa hokum-hukum yang terdapat dalam Al-Qur'an dan As-Sunah (syari'ah), serta hukum-hukum yang dihasilkan oleh para ahli hukum Islam dengann menggunakan ijtihad. ${ }^{5}$ Hokum dalam kajian ushul fikih umumnya dimaksudkan sebagai hokum syariat yang berarti ketentuan Allah yang S.W.T. yang berkaitan dengan segala perbuatan hamba yang telah diwajibkan untuk mengembannya, baik berupa tuntutan, pilihan, maupun pertimbangan. ${ }^{6}$ Jadi hukum berarti

${ }^{4}$ Dalam terma fiqh, istilah memiliki daya paksa dan tidak memiliki daya paksa dikenal dengan sebutan mulzim-ghair mulzim.

${ }^{5}$ Abdurrahman MPB. (2015). Harmonisasi Hukum Adat dan Hukum Islam bagi Pengembangan Hukum Nasional. AlMashlahah: Jurnal Hukum dan Pranata Sosial Islam, 03(06). hlm. 369.

6 Rahendra Maya. (2018). Konstruk Syariah Hadits Ahkam (Syarah Ahâdîts AlAhkâm) dan Format Pembelajarannya di Perguruan Tinggi: Sebuah Tawaran 
menetapkan sesuatu atas sesuatu atau meniadakan sesuatu, ${ }^{7}$ Secara umum Hukum Islam adalah the living law atau hukum yang hidup dalam masyarakat, bukan iusconstitutum dan bukan pula ius constituendum. Hukum positif adalah hukum yang diformulasikan oleh institusi negara dan tegas kapan dinyatakan berlaku dan kapan tidak berlaku lagi. The Living law tidak diformulasikan oleh negara, tetapi hukum itu hidup dalam alam pikiran dan kesadaran hukum masyarakat. Ia berpengaruh dalam kehidupan masyarakat dan kadang-kadang daya pengaruhnya bahkan mengalahkan hukum positif yang diformulasikan oleh negara. Hukum yang hidup itu bersifat dinamis sejalan dengan perkembangan masyarakat. ${ }^{8}$

Dalam catatan sejarah sejak berdirinya MUI sampai dengan sekarang telah banyak fatwa, saran, dan rekomendasi MUI sebagai bagian dari pemikiran hukum Islam yang terserap

Metodologis. Al-Mashlahah: Jurnal Hukum Islam dan Pranata Sosial Islam, 06(01). hlm. 25.

${ }^{7}$ Eka Sakti Habibullah. (2017). Hukum Ekonomi Syariah dalam Tatanan Hukum Nasional. Al-Mashlahah: Jurnal Hukum Islam dan Pranata Sosial Islam, 05(10). hlm. 699.

${ }^{8}$ Hukum Islam adalah the living law, ini pandangan Prof Yusril terkait Fatwa MUI soal atribut natal https://www.salam-online.com. dalam berbagai peraturan perundangundangan (taqnīn).

Efektifitas fatwa dalam mengatur perilaku masyarakat atau menyelesaikan permasalahan yang dihadapi sangat tergantung kepada tingkat ketaatan umat kepada Allah dan Rasul-Nya serta otoritas ulama (sebagai uli al-amr) yang mengeluarkan fatwa. Fatwa MUI merupakan pendapat hukum yang dibuat (diproduksi) oleh MUI dimana "produser" fatwanya harus memiliki kapasitas keilmuan di bidang hukum Islam untuk menjawab pertanyaan tertentu berdasarkan Alquran dan Sunnah Rasulullah.

Selanjutnya bagaimana hubungan antara fatwa dengan peraturan yang berlaku dalam suatu negara hukum, mengingat baik fatwa atau hukum merupakan norma atau aturan kehidupan yang berada dalam masyarakat. Perdebatan hukum di Indonesia terletak pada mengikat atau tidak mengikatnya suatu ketetapan hukum jika diproduksi di luar peraturan perundang-undangan. Untuk mereduksi ini, MUI mengupayakan proses menjadikan fatwa bertransformasi menjadi undang-undang (legalisasi fatwa; taqnin). 
Indonesia adalah negara hukum berdasarkan Pancasila dan UndangUndang Dasar 1945. Hal ini dinyatakan bahwa Negara Republik Indonesia adalah negara yang didasarkan atas Ketuhanan Yang Maha Esa. Menurut Hazairin seorang guru besar Universitas Islam Indonesia (UII) berpendapat bahwa norma dasar yang tersebut dalam pasal 29 Ayat (1) tafsirannya antara lain, hanya mungkin (Demokrasi Pancasila). Dalam Negara Republik Indonesia tidak boleh terjadi atau berlaku sesuatu yang bertentangan dengan kaidah-kaidah Islam bagi umat Islam, atau yang bertentangan dengan kaidah-kaidah Nasrani bagi umat Nasrani, atau yang bertentangan dengan kaidah-kaidah agama Hindu bagi umat Hindu-Bali, atau bertentangan dengan agama Budha bagi orang-orang Budha. Ini berarti di dalam Negara Republik Indonesia tidak boleh berlaku atau diberlakukan hukum yang bertentangan dengan norma-norma (hukum) agama dan norma-norma kesusilaan bangsa. ${ }^{9}$

Menurut Ketetapan MPR Nomor II/MPR/1978; salah satu wujud pengamalan sila Ketuhanan yang Maha

${ }^{9}$ Muhammad Daud Ali. (2009). Hukum Islam. Jakarta: PT RajaGrafindo Persada. hlm. 7.
Esa itu adalah percaya kepada Tuhan Yang Maha Esa sesuai dengan agama dan kepercayaannya masing-masing menurut dasar kemanusiaan yang adil dan beradab. Ketetapan Allah yang langsung berhubungan dengan kehidupan manusia dengan manusia (bidang mu'āmalah) terbatas pada masalah yang berhubungan dengan pahala saja. Penjelasan Nabi kalaupun ada, tidak dijelaskan secara terperinci, berbeda dengan penjelasan aturanaturan yang berhubungan bidang ibadah. Hukum Islam sifatnya terbuka untuk dikembangkan melalui ijtihad manusia dengan keharusan memenuhi persyaratan dalam pengembangan hukum tersebut. Kaidah asal untuk mu'àmalah adalah kebolehan (jāiz atau ibāhah), 10 "Hukum asal dalam mu'amalah adalah kebolehan sampai ada dalil yang menunjukkan keharamannya".

Tinjauan filsafat Hukum Islam, hukum Islam dapat dirinci sebagai berikut: 1) Hukum yang berkembang, dinamis, elastic, dan fleksibel. 2) Dibangun dengan asas-asas yang kuat.

\footnotetext{
${ }^{10}$ A Djazuli. (2006). Kaidah-kaidah Fiqh: Kaidah-kaidah Hukum Islam dalam Menyelesaikan Masalah-masalah yang Praktis. Jakarta: Kencana. hlm. 10.
} 
3) Hukum dengan berwatak dan bertabiat kuat. 4) Hukum mempunyai keindahan dan keistimewaan dibanding dengan hukum-hukum syari'at lain.

Dengan demikian, hukum dibuat untuk memenuhi kepentingan masyarakat dan dipergunakan untuk menanggulangi berbagai persoalan dan juga untuk mendatangkan kemaslahatan masyarakat yang terus tumbuh. Kemaslahatan masyarakat dalam urusan mu'āmalah adalah suatu dasar asasi dalam pembinaan hukum; tidak heran kalau hukum sering dipengaruhi oleh letak geografis dan waktu tertentu. Ibnu Qayyim berkaitan dengan hal tersebut berkata: "Sesungguhnya syari'at itu fondasi dan asasinya ialah hikmah dan kemaslahatan hamba, baik dalam kehidupan dunia maupun kehidupan akhirat". ${ }^{11}$

Hukum Islam dihadapkan kepada bermacam-macam etnis atau kelompok manusia di seluruh dunia. Maka tentu Pembina Hukum memperhatikan kemaslahatan masing-masing mereka sesuai dengan adat dan kebudayaan mereka serta iklim yang menyelubunginya. Jika kemaslahatan

11 T.M. Hasbi Ash-Shiddieqy. (1975). Falsafah Hukum Islam. Jakarta: Bulan Bintang. hlm. 79. itu bertentangan satu sama lain, maka kaidah yang berlaku pada kasus itu adalah dilakukan kaidah mashlahat umum atas mashlahat khusus dan kaidah dilakukan penolakan kemadharatan yang lebih besar dengan jalan mengerjakan kemadharatan kecil.

Kemaslahatan dalam urusan mu'āmalah misalnya, dimaksudkan sebagai aturan-aturan (hukum) Allah S.W.T. yang ditujukan untuk mengatur kehidupan manusia dalam urusan keduniaan atau urusan duniawi dan sosial kemasyarakatan. Kapanpun dan di manapun, harus senantiasa mengikuti ketetapan tersebut, karena semua aktivitas manusia akan diminta pertanggungjawabannya kelak di akhirat; sekecil apapun aktivitas manusia didasarkan pada ketetapan Allah S.W.T, agar selamat dunia akhirat.

Problematika yang dihadapi bangsa Indonesia, khususnya umat Islam sering kali berurusan dengan masalah hukum; dan perundang-undangan nasional (masāil qānūniyah) seperti hal-hal yang berhubungan dengan Ekonomi Syari'ah, termasuk di dalamnya gadai (rahn), BPJS, Perbankan Syari'ah, Kartu Kredit, Surat Jaminan, Pelayanan 
Miniatur Ekonomi Sosial, dan lain-lain. Kesemua permasalahan tersebut perlu jawaban dan ketetapan hukum yang pasti. $^{12}$

Posisi MUI sebagai institusi yang keputusan-keputusannya didukung oleh pemerintah bahkan pemerintah sendiri memperlakukan MUI sebagai representatif dari keseluruhan umat Islam Indonesia, sekalipun ada sekelompok kecil yang tidak merasa diwakilinya.

Sebagai negara hukum, ketentuanketentuan yang berlaku di Indonesia tidak boleh bertentangan dengan kaidah-kaidah agama yang diakui Indonesia, termasuk kaidah-kaidah dalam Islam. Negara wajib memberikan fasilitas sepanjang hal tersebut memerlukan perantara kekuasaan negara; antara lain melalui pembentukan peraturan perundangundangan, agar tidak bertentangan dengan kaidah-kaidah agama tersebut.

Perkembangan kehidupan masyarakat ternyata tidak seluruh kebutuhan hukum masyarakat terpenuhi

12 Pada kasus Ekonomi Islam, MUI membuat lembaga yang disebut dengan DSNMUI (Dewan Syariah Nasional-Majelis Ulama Indonesia. DSN banyak membuat fatwa dan menerbitkannya, sebagai bahan acuan dalam kepastian hukum muamalah (ekonomi). melalui peraturan yang dibuat oleh pemerintah. Di antara lembaga-lembaga yang dapat memenuhi kekosongan hukum untuk memecahkan permasalahan dalam bidang hukum Islam yang sering dilibatkan oleh pemerintah dalam proses penerbitan suatu peraturan yang berhubungan dengan Hukum Islam adalah MUI, sebagai salah satu organisasi masyarakat yang berasaskan Islam. Bahkan "MUI ini merupakan lembaga yang menerbitkan fatwa-fatwa sejak tahun 1976 sampai dengan saat ini”. ${ }^{13}$

Sejalan dengan peran dan fungsinya, baik diminta atau tidak diminta, MUI menetapkan fatwa didasarkan atas permintaan atau pertanyaan dari kalangan masyarakat, pemerintah, lembaga/organisasi sosial maupun perkembangan dan temuan masalah-masalah keagamaan yang muncul akibat perubahan masyarakat dan kemajuan ilmu pengetahuan dan teknologi.

Hal yang sangat menarik berkaitan dengan fatwa-fatwa yang dikeluarkan

\footnotetext{
${ }^{13}$ Wahiduddin Adam, dkk. (2012). Fatwa Majelis Ulama Indonesia (MUI) dalam Prespektif Hukum dan Perundang-undangan. Jakarta: Badan Litbang dan Diklat Kementrian Agama RI. hlm. 272.
} 
oleh MUI dalam lembaganya dengan peraturan perundang-undangan yang berlaku di Indonesia, bahwa fatwafatwa MUI ini diklasifikasikan ada tiga kategori, yaitu; fatwa tentang kehalalan produk, kemasyarakatan, dan ekonomi syari'ah. Hanya saja dari ketiga kategori ini yang memiliki kedudukan yang sangat kuat jika dibandingkan dengan dua kategori (kehalalan produk dan kemasyarakatan) yaitu fatwa-fatwa kategori ekonomi syari'ah, karena diakui dan dikuatkan keberadaannya serta dituangkan dalam perundangundangan negara yang berlaku di Indonesia; sehingga jika ada pihakpihak yang melanggar atau tidak melaksanakan fatwa-fatwa tersebut akan dikenakan sanksi administratif dari pemerintah bahkan akan dikenakan sanksi pidana bagi pihak yang menerbitkan label halal yang tidak sesuai dengan fatwa halal dari MUI.

Fatwa-fatwa Dewan Syari'ah Nasional (DSN) menjadi pedoman bagi pihak-pihak yang melaksanakan kegiatan usaha berdasarkan prinsip syari'ah dalam melaksanakan berbagai kegiatan operasionalnya. Hal ini tentunya memberi pengaruh dalam penyelesaian perkara hukum di pengadilan, sehingga para hakim dalam memutuskan perkaranya sudah seharusnya berpedoman pada fatwafatwa DSN, karena dalam perundangundangan yang berlaku ditentukan bahwa kegiatan ekonomi syari'ah tersebut berpedoman pada fatwa DSN. ${ }^{14}$

MUI memiliki otoritas memproduksi dan menurunkan fatwa (otoritatif) untuk dijadikan pedoman atau acuan masyarakat muslim. Pada saat yang sama, MUI tidak memiliki otoritas paksa atas fatwa yang diturunkan. Karenanya upaya taqnīn (transformasi fatwa MUI menjadi undang-undang), menjadi sebuah keniscayaan dalam legalitas kenegaraan suatu fatwa supaya memiliki daya rekat atau mengikat dan daya paksa pada pelaksanaannya.

Kasus fatwa pada bidang jinâyah (pidana) misalnya, Surat Keputusan Fatwa (SKF) MUI tidak memiliki daya paksa pada tingkat penerapan sangsi karena fatwa secara umum dan fatwa MUI secara khusus tidak memiliki otoritas memaksa secara hukum formal. Karenanya upaya-upaya takhrīj al-Ahkām, mengembangkan

${ }^{14}$ Wahiduddin Adam, dkk. (2012). hlm. 275. 
fatwa pada level otoritasnya menjadi undang-undang adalah keniscayaan, dengan tujuan efektifitas fatwa pada aspek otoritas pemaksaan dan sangsisangsi.

Berlatar belakang perspektif pembinaan hukum tentang MUI sebagai lembaga yang mengeluarkan/menetapkan fatwa atas segala permasalahan yang timbul di masyarakat terutama yang tidak ada ketetapan hukumnya baik dalam Alqurân atau Hadits atau kitab-kitab fikih klasik; maka masalah penelitian ini adalah bahwa pembinaan hukum demi terciptanya kemaslahatan masyarakat Indonesia khususnya, masih banyak permasalahan-permasalahan yang ketetapan hukumnya belum dapat diketahui masyarakat sehingga masyarakat khawatir dan penuh keraguan dalam tindakan-tindakannya; baik yang berhubungan dengan bidang teknis ibadah, sosial budaya (mu'āmalah), maupun bidang pidana (jināyah). Peran dan kontribusi MUI perlu diteliti pada aspek perkembangan dan penerapan hukum Islam di Indonesia. Selain itu, argumenargumen (dalīl) yang dibangun dalam penetapan hukum Islam oleh MUI perlu diteliti; baik dari teks Alquran, Sunnah maupun komponen ijtihad. Berdasarkan rumusan masalah dalam bentuk pernyataan tersebut, dapat diajukan pertanyaan penelitian sebagai berikut: (1) Bagaimana peran MUI dalam pengembangan dan penerapan hukum Islam dalam bidang keagamaan dan DSN; (2) Bagaimana metodologi istinbat dan istidlāl yang digunakan MUI dalam pengembangan dan penerapan hukum Islam di Indonesia; dan (3) Bagaimana kontribusi MUI dalam pengembangan dan penerapan hukum Islam di Indonesia.

Adapun tujuan penelitian yang ingin dicapai penulis adalah sebagai berikut: (1) Menganalisis peran MUI dalam pengembangan dan penerapan hukum Islam dalam bidang keagamaan dan DSN; (2) Menganalisis metodologi istinbat dan istidlāl yang digunakan MUI dalam pengembangan dan penerapan hukum Islam di Indonesia; dan (3) Menganalisis kontribusi MUI dalam pengembangan dan penerapan hukum Islam di Indonesia.

\section{B. KERANGKA TEORI DAN TINJAUAN PUSTAKA}

Penelitian pengembangan dan penerapan hukum Islam di Indonesia, 
menggunakan beberapa teori sebagai berikut:

Grand Theory: Pada tataran grand theory digunakan teori kredo (credo). Sebuah teori yang menjelaskan pelaksanaan hukum Islam dikaitkan dengan pernyataan dua kalimah syahadat, sehingga teori ini dinamakan juga dengan teori syahādah. Berdasarkan teori ini bahwa setiap orang yang telah mengucapkan dua kalimah syahādah harus menggunakan hukum Islam sebagai konsekuensi logis dari pengucap kredonya. ${ }^{15}$

Teori kredo ini merupakan kelanjutan dari prinsip tauhid dalam filsafat hukum Islam yang mengharuskan pelaksanaan hukum Islam oleh mereka yang telah mengucapkan dua kalimah sahādah. ${ }^{16}$ Prinsip tauhid membawa implikasi bahwa setiap orang yang telah mendeklarasikan dirinya beriman kepada ke-Maha Esa-an Allah, wajib

${ }^{15}$ Juhaya S. Praja. (1995). Filsafat Hukum Islam. Bandung: LPPM UNISBA. hlm. 133; dan Juhaya S. Praja. (2000). Aspek Sosiologi dalam Pembaharuan Fiqih di Indonesia. dalam Anang Haris Himawan "Epistemologi Syara' Mencari Format Baru Fiqih Indonesia". Yogyakarta: Pustaka Pelajar. hlm. 125.

16 Mhsun Fuad. (2005). Hukum Islam Indonesia: Dari Nalar Pastisipatoris Hingga Emansipatoris. Yogyakarta: LkiS. hlm. 50. taat terhadap segala perintah Allah. ${ }^{17}$ Tauhid merupakan prinsip umum hukum Islam. Prinsip ini menyatakan bahwa manusia ada di bawah satu ketetapan yang sama, yaitu ketetapan tauhid yang diverbalkan dalam bentuk statement "Là ilāha illa Allāh" (tidak ada Tuhan yang wajib disembah selain Allah). Prinsip ini diambil dari intisari firman Allah dalam Surat Ali Imran [3]: 64:

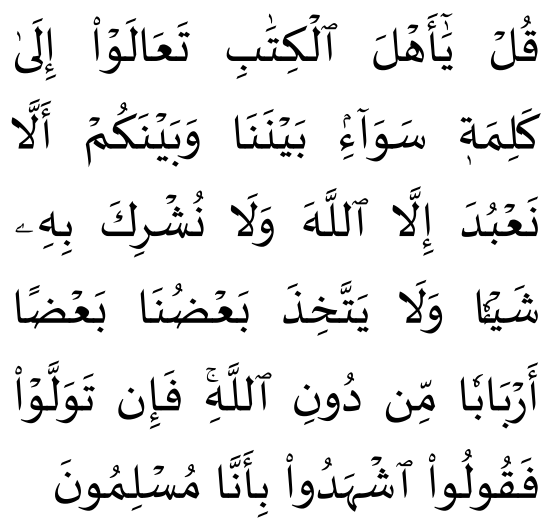

"Katakanlah: "Hai ahli kitab, marilah (berpegang) kepada suatu kalimat (ketetapan) yang tidak ada perselisihan antara kami dan kamu, bahwa tidak kita sembah kecuali Allah dan tidak kita sekutukan Dia dengan sesuatupun dan tidak (pula) sebagian kita menjadikan sebgaian yang lain sebagai Tuhan selain Allah".

\footnotetext{
${ }^{17}$ Mhsun Fuad. (2005). hlm. 50.
} 
Jika mereka berpaling maka katakanlah kepada mereka: "Saksikanlah bahwa kami adalah orang-orang yang berserah diri (kepada Allah)."

Berdasarkan teori syahadat yang dikuatkan oleh teori non teritorial ini, umat Islam Indonesia yang telah menyatakan dua kalimah syahadat wajib melaksanakan perwalian, baik dalam hukum perkawinan maupun dalam hukum bisnis sebagai konsekuensi logis atas kredonya.

Middle Theory: Pada tahap middle theory, penulis menggunakan teori perkembangan hukum Islam. Pemilihan teori ini merupakan sebuah upaya untuk menggali suatu hukum yang sudah pada zaman Rasulullah S.A.W., hingga dalam perkembangannya ijtihad dilakukan oleh para sahabat, tabi' in serta masa-masa selanjutnya sampai sekarang. Teori perkembangan hukum Islam di Indonesia tidak dapat dilepaskan dari rentang prakemerdekaan. Yang pertama muncul adalah teori receptive; bahwa hukum dapat diterima jika sudah diterima oleh hukum adat. Kemudian muncul teori receptie a contrario sebagai kebalikan dari teori receptie. Pada perkembangan berikutnya, hukum Islam sudah masuk pada wilayah yang lebih luas dan dimanifestasikan dalam bentuk lembaga-lembaga tertentu.

Aplicative Theory: Pada tataran aplikatif, penulis menggunakan teori Taqnīn Al-Ahkām Abdullah bin AlMuqaffa. Teori ini dipilih karena pemberlakuan sebuah aturan atau hukum dalam Islam di Indonesia bersifat tidak mengikat dan untuk dapat mengikat maka perlu ada upaya menjadikan fatwa MUI bertransformasi menjadi undang-undang. Undangundang dapat dinyatakan sebagai peraturan perundang-undangan yang tertinggi, di dalamnya telah dapat dicantumkan adanya sanksi dan sekaligus dapat langsung berlaku dan mengikat masyarakat secara umum.

\section{PEMBAHASAN}

\section{Sejarah MUI}

MUI berdiri sebagai hasil dari pertemuan atau musyawarah para ulama, cendekiawan, dan zu'ama yang datang dari berbagai penjuru tanah air, antara lain meliputi dua puluh enam orang ulama yang mewakili 26 Provinsi di Indonesia pada masa itu, 10 orang ulama yang merupakan unsur dari 
ormas-ormas Islam tingkat pusat, yaitu, NU, Muhammadiyah, Syarikat Islam, Perti. Al-Washliyah, Math'laul Anwar, GUPPI, PTDI, DMI, dan Al Ittihadiyyah, 4 orang ulama dari Dinas Rohani Islam, Angkatan Darat, Angkatan Udara, Angkatan Laut dan POLRI serta 13 orang tokoh cendekiawan yang merupakan tokoh perorangan. Dari musyawarah tersebut, dihasilkan sebuah kesepakatan untuk membentuk wadah tempat musyawarah para ulama, zu'amâ dan cendekiawan muslim, yang tertuang dalam sebuah Piagam Berdirinya MUI, yang ditandatangani oleh seluruh peserta musyawarah yang kemudian disebut Musyawarah Nasional Ulama I.

Momentum berdirinya MUI bertepatan ketika bangsa Indonesia tengah berada pada fase kebangkitan kembali, setelah 30 tahun merdeka, di mana energi bangsa telah banyak terserap dalam perjuangan politik kelompok dan kurang peduli terhadap masalah kesejahteraan rohani umat. Selama dua puluh lima tahun, MUI sebagai wadah musyawarah para ulama, $z u^{\prime} a m \bar{a}$, dan cendekiawan muslim berusaha untuk: a. Memberikan bimbingan dan tuntunan kepada umat Islam Indonesia dalam mewujudkan kehidupan beragama dan bermasyarakat yang diridhai Allah.

b. Memberikan nasihat dan fatwa mengenai masalah keagamaan dan kemasyarakatan kepada pemerintah dan masyarakat, meningkatkan kegiatan bagi terwujudnya hubungan keislaman dan kerukunan antarumat beragama dalam memantapkan persatuan dan kesatuan bangsa,

c. Menjadi penghubung antara ulama dan pemerintah dan penerjemah timbal balik antara umat dan pemerintah guna menyukseskan pembangunan nasional.

d. Meningkatkan hubungan serta kerjasama antar organisasi, lembaga Islam, dan cendekiawan muslimin dalam memberikan bimbingan dan tuntunan kepada masyarakat khususnya umat Islam dengan mengadakan konsultasi dan informasi secara timbal balik. 
2. Penerapan dan Pengembangan Fatwa MUI dalam Bidang Akidah, Ibadah, Mu'amalah, dan DSN

Peran MUI dalam pengembangan dan penerapan Hukum Islam dalam bidang akidah adalah dengan memproduksi fatwa sebanyak 10 fatwa dalam rentang tahun 2010 hingga 2017, dari 19 fatwa jika dihitung dalam rentang tahun 1978-2017. Fatwa tersebut memberi kepastian hukum bagi umat Islam dan mendorong pemerintah untuk mengawal fatwa MUI serta membuat regulasi pada persoalan akidah.

Peran MUI dalam pengembangan dan penerapan Hukum Islam dalam rentang tahun 2000-2017 dalam bidang ibadah dengan memproduksi 19 fatwa dari 39 fatwa jika dihitung dalam rentang tahun 1978 hingga 2017. Fatwa tersebut menjadi payung hukum bagi umat dalam pelaksanaan ibadah dan menghilangkan keraguan karena sudah mendapat fatwa dari lembaga yang memiliki otoritas.

Peran MUI dalam pengembangan dan penerapan Hukum Islam dalam bidang muamalah (sosial dan budaya) dengan memproduksi fatwa sebanyak 35 fatwa dari 57 fatwa MUI jika dihitung dalam rentang tahun 1978 hingga tahun 2017.

Peran MUI dalam pengembangan dan penerapan Hukum Islam dalam bidang jināyah ditemukan fatwa sebanyak 10 fatwa dari 10 fatwa MUI jika dihitung dalam rentang tahun 1978 hingga 2017. Melalui fatwa tersebut MUI mendorong pemerintah untuk membuat undang-undang terkait tindak pidana dengan draf rancangan undangundang yang sudah dibuat oleh MUI.

Fatwa DSN-MUI rentang 20002017 sebanyak 116 fatwa dari total fatwa 116 fatwa sejak awal produksi fatwa DSN. Fatwa DSN terhitung dari tahun 2000 sehingga jumlahnya akan bertambah jika dihitung dengan fatwa DSN terkini. Fatwa DSN ini bersifat mengikat karena sudah direkomendasi ketetapan hukumnya oleh pemerintah (BI) dalam urusan perbankan syari'ah. Fatwa dalam bidang muamalah didominasi atau mayoritas membicarakan pada aspek hukum ekonomi syari'ah.

Pengembangan metodologi istinbāth dan Iistidlāl hukum yang digunakan MUI dalam menerapkan hukum di Indonesia merujuk pada kaidah-kaidah yang telah dibuat oleh 
para ulama fiqh terdahulu dengan merujuk pada teks Alquran, Sunnah, Ijmā', Qiyās, Istihsān, Istișhab, Mașālih Al-Mursalah, Sad Al-Dirā'ah dengan tahapan dan pertimbanganpertimbangan tertentu dalam penetapan hukumnya. Pada wilayah mu'amalah, aspek yang dikedepankan adalah aspek maslahah (kemaslahatan). Istinbat hukum yang dominan pada bidang akidah adalah pengeluaran hukum dari Alquran dan Al-Sunnah; pada bidang ibadah istinbat hukum yang dominan adalah teks Alquran dan Al-Sunnah ditambah dengan qiyas pada beberapa kasus; pada bidang muamalah istinbat hukum yang dominan adalah istishab pada kaidah al-aṣl fi al-asyyā al-ibāhah.

Kontribusi MUI dalam pengembangan dan penerapan Hukum Islam di Indonesia adalah terbagi kepada dua bagian; pertama, kontribusi atau sumbangsih pada kepastian hukum bagi umat Islam itu sendiri secara individu atau kelompok umat Islam dan kedua, pada taqnin atas fatwa-fatwa yang telah dibuat. Pada bagian kedua ini fatwa sudah bertransformasi kepada undang-undang, Peraturan Pemerintah (PP); dimana posisi MUI sebagai pengusul draf Rancangan Undang- undang (RUU) atau pengusul dengan memberikan draft Rancangan Peraturan Pemerintah (RPP). Posisi fatwa merupakan bahan dasar dari pembuatan undang-undang. Pada posisi lain, fatwa secara utuh digunakan sebagai rujukan atas amanat undang-undang atau peraturan tertentu. Pada kasus DSN, seluruh fatwanya menjadi acuan bagi pelaksanaan ekonomi syari'ah yang payung hukumnya dari Bank Indonesia (BI).

Kontrubusi MUI dapat berupa dukungan terhadap lahirnya UU atau Perda tertentu. Pada kasus UU Pornografi, MUI bersama ormas lain berada pada barisan pendukung lahirnya UU tersebut. Kontribusi lain dari MUI dapat terlihat dari usulan-usulan MUI ketika UU tertentu muncul. Usulan dapat berupa aktivasi UU dalam bentuk Peraturan Pemerintah (PP), Peraturan Menteri Agama (PMA) atau kementrian dan lembaga-lembaga lain.

Ada beberapa fatwa yang sudah bertransformasi menjadi UU, di antaranya adalah: (1) Rancangan Undang-Undang (RUU) Jaminan Produk Halal; (2) Undang-Undang Nomor 21 Tahun 2008 tentang Perbankan Syariah; (3) Undang-Undang 
Nomor 44 Tahun 2008 tentang Pornografi; (4) Peraturan Pemerintah (PP) No. 15 Tahun 2014 tentang syarat dan tata cara perizinan pembuatan, penyebarluasan dan penggunaan produk pornografi; (5) Rancangan UndangUndang (RUU) Hukum Materil Peradilan Agama bidang Perkawinan; (6) Undang-Undang Nomor: 41 Tahun 2004 tentang wakaf, dan Peraturan Pemerintah Nomor 42 Tahun 2006 tentang Pelaksanaan Undang-Undang Nomor 41 Tahun 2004 tentang wakaf; (7) Undang-Undang Nomor 13 Tahun 2008 tentang Penyelenggaraan Ibadah Haji; (8) Peraturan Mahkamah Agung Nomor 2 Tahun 2008 tentang Kompilasi Hukum Ekonomi Syariah; (9) Peraturan Pemerintah Nomor 55 Tahun 2007 tentang Pendidikan Agama dan Keagamaan; (10) Rancangan Undang-Undang (RUU) tentang Perubahan Undang-Undang Mengenai lembaga Mahkamah Agung (MA); (11) Rancangan Undang-Undang (RUU) tentang Pemilihan Umum (PEMILU) Kepala Daerah; (12) Rancangan Undang-Undang (RUU) tentang Kitab Undang-Undang Hukum Pidana (KUHP); (13) Rancangan UndangUndang (RUU) tentang Kesetaraan dan
Keadilan Gender ;(14) Rancangan Undang-Undang (RUU) tentang Kerukunan Umat Beragama; (15) Rancangan Undang-Undang (RUU) tentang Perguruan Tinggi; (16) Rancangan Peraturan Pemerintah (RPP) tentang Kedudukan Anak sebagai Pelaksana Undang-Undang Perkawinan; dan (17) Amandemen UUD 1945. Jika dilirinci dalam bentuk satuan UU atau Peraturan Pemerintah (PP). Maka fatwa MUI yang sudah bertransformasi menjadi UU atau PP jumlahnya cukup banyak, karena fatwa DSN yang sudah dianggap mengikat karena sudah dijadikan payung hukum oleh Bank Indonesia (BI) untuk regulasi pada bank-bank syari'ah, ditambah dengan fatwa-fatwa di bidang selain DSN yang juga sudah ada yang bertransformasi menjadi UU atau Peraturan Pemerintah (PP).

\section{KESIMPULAN}

Penelitian tentang kontribusi MUI dalam penerapan dan pengembangan hukum Islam di Indonesia mencakup pemproduksian fatwa dari beberapa bidang: aqīdah, 'ibādah, mu'āmalah, jināyah, dan fatwa bidang Ekonomi 
Islam yang dikeluarkan oleh Dewan Syari'ah Nasional (DSN-MUI).

Selanjutnya adalah metodologi istinbāt dan istidlāl atas fatwa yang akan diproduksi. Pada kajian ini para ulama yang duduk di lembaga MUI membuat tahapan-tahapan; jika hukum dalam Alquran dan As-Sunnah sudah tegas maka fatwa hanya menegaskan apa yang sudah ada dalam dua sumber tersebut. Jika tidak terdapat pada dua sumber tersebut maka dilakukan upaya ijtihād dengan menggunakan pilihanpilihan metodologis; ijmā', qiyās, istihsān, istiṣhāb, maṣālih al-mursalah atau sad al-dirā'ah. Metodologi tersebut digunakan berdasar pada obyek yang akan dikeluarkan hukumnya.

Demikian tulisan ini dibuat untuk mengilustrasikan kontribusi MUI dalam pengembangan dan penerapan hukum Islam di Indonesia baik kontrubusi yang bersifat internal bagi individu-individu umat Islam maupun bertransformasi menjadi legal formal.

\section{DAFTAR PUSTAKA}

\section{Sumber dari Jurnal/Penelitian}

Habibullah, E.S. (2017). Hukum Ekonomi Syariah dalam Tatanan Hukum Nasional. Al-Mashlahah: Jurnal Hukum Islam dan Pranata Sosial Islam, 05(10).
Maya, R. (2018). Konstruk Syariah Hadits Ahkam (Syarah Ahâdîts AlAhkâm) dan Format Pembelajarannya di Perguruan Tinggi: Sebuah Tawaran Metodologis. Al-Mashlahah: Jurnal Hukum Islam dan Pranata Sosial Islam, 06(01).

MPB. Abdurrahman. (2015). Harmonisasi Hukum Adat dan Hukum Islam bagi Pengembangan Hukum Nasional. Al-Mashlahah: Jurnal Hukum dan Pranata Sosial Islam, 03(06).

\section{Sumber dari Buku}

Adam, W. dkk. (2012). Fatwa Majelis Ulama Indonesia (MUI) dalam Prespektif Hukum dan Perundangundangan. Jakarta: Badan Litbang dan Diklat: Kementrian Agama RI.

Ali, M.D. (2009). Hukum Islam. Jakarta: PT RajaGrafindo Persada.

Ash Shiddieqy, T.M.H. (1975). Falsafah Hukum Islam. Jakarta: Bulan Bintang.

Djazuli, A. (2006). Kaidah-kaidah Fiqh: Kaidah-kaidah Hukum Islam dalam Menyelesaikan Masalahmasalah yang Praktis. Jakarta: Kencana.

Djazuli, A. (2006). Islam Fiqh: Penggalian, Perkembangan dan Penerapan Hukum Islam. Jakarta: Rosdakara.

Fuad, M. (2005). Hukum Islam Indonesia: Dari Nalar Pastisipatoris Hingga Emansipatoris. Yogyakarta: LkiS.

Praja, J.S. (2000). Aspek Sosiologi dalam Pembaharuan Fiqih di Indonesia, dalam Anang Haris 
Himawan "Epistemologi Syara' Mencari Format Baru Fiqih Indonesia”. Yogyakarta: Pustaka Pelajar.

Praja, J.S. (1995). Filsafat Hukum Islam. Bandung: LPPM UNISBA.

\section{Sumber dari Internet}

www.salam-online.com

https://news.detik.com/berita/3397842/ mahfud-md-fatwa-mui 